\title{
EMERGENCY RIGHT HEPATECTOMY FOR PORTA HEPATIS INJURY DURING LAPAROSCOPIC CHOLECYSTECTOMY
}

\author{
Hepatectomia direita de emergência para lesão do hilo hepático durante colecistectomia laparoscópica
}

Olival Cirilo Lucena da FONSECA-NETO, Américo Gusmão AMORIM, Jacinto Ferreira LMA, Cláudio Moura Lacerda de MELO

From the Serviço de Cirurgia Geral e Transplante Hepático do Hospital Universitário Oswaldo Cruz, Universidade de Pernambuco (General Surgery and Liver Transplant Service, Oswaldo Cruz Teaching Hospital, University of Pernambuco), Recife, PE, Brazil.

\section{Correspondence:}

Olival Cirilo Lucena da Fonseca Neto

E-mail: olivalneto@globo.com

Financial source: none

Conflicts of interest: none

Received for publication: 23/08/2012

Accepted for publication: 10/09/2013

\section{INTRODUCTION}

aparoscopic cholecystectomy is the surgical procedure of choice for symptomatic gallstones. The incidence of bile duct injury following laparoscopic cholecystectomy is around $0.62 \%$ and, when vascular injuries also occur, the surgeon is faced with is a serious complication ${ }^{1}$. Morbidity and mortality increase drastically when bileduct and vascular injuries occur simultaneously and a successful outcome is unlikely when diagnosis of these is delayed. The extent of liver damage and the need for liver resection or transplant significantly influence the progress of patients with such injuries.

\section{CASE REPORT}

A 36-year-old female with symptomatic colelithiasis was referred for elective laparoscopic cholecystectomy. During the surgery, the chronic inflammatory process deforming the anatomy of the porta hepatis and the appearance of bleeding and bile in the surgical field obliged the surgeons to revert to the conventional procedure (open cholecystectomy), which involves a subcostal incision on the right hand side. Extensive hemostasis was carried out using sutures, clips and diathermy. The assistant surgeon decided to call in the surgeons from the hepato-biliary surgery group. The new team immediately increased the size of the incision (extending it to the subcostal area on the left hand side). Almost complete damage to the elements of the porta hepatis was found: ligature and section of the right portal branch; ligature and section of the right hepatic artery; ligature and section of the common hepatic duct on bifurcation; ligature and almost complete section of the left hepatic artery.

It was decided to revascularize the left hepatic artery (dissection, resection of the damaged segment primary anastomosis with prolene 7.0). Right hepatectomy was carried out without incident. After resection of the liver an end-to-side Roux-en-Y loop hepaticojejunostomy was carried out on the left hepatic duct. Owing to bleeding during surgery, the patient received five red blood cell concentrates and $3 \mathrm{u}$ of fresh plasma. She also received a continuous infusion of antifibrinolytic (ipsilon $($ ) ) during and after surgery. The patient remained in intensive care for five days, initially with mild liver dysfunction and nondialysis kidney failure $(\mathrm{Cr}>2 \mathrm{mg} / \mathrm{dl}$ and INR $>1.7)$. The patient received metabolic and nutritional backup to deal with the organ dysfunctions. She was discharged from hospital after 21 days.

After six months she was readmitted to hospital to successfully carry out dilation of the stenosis of the biliary system. Eighteen months after surgery she was free of any complications in the remaining part of the liver (Figures 1 and 2).

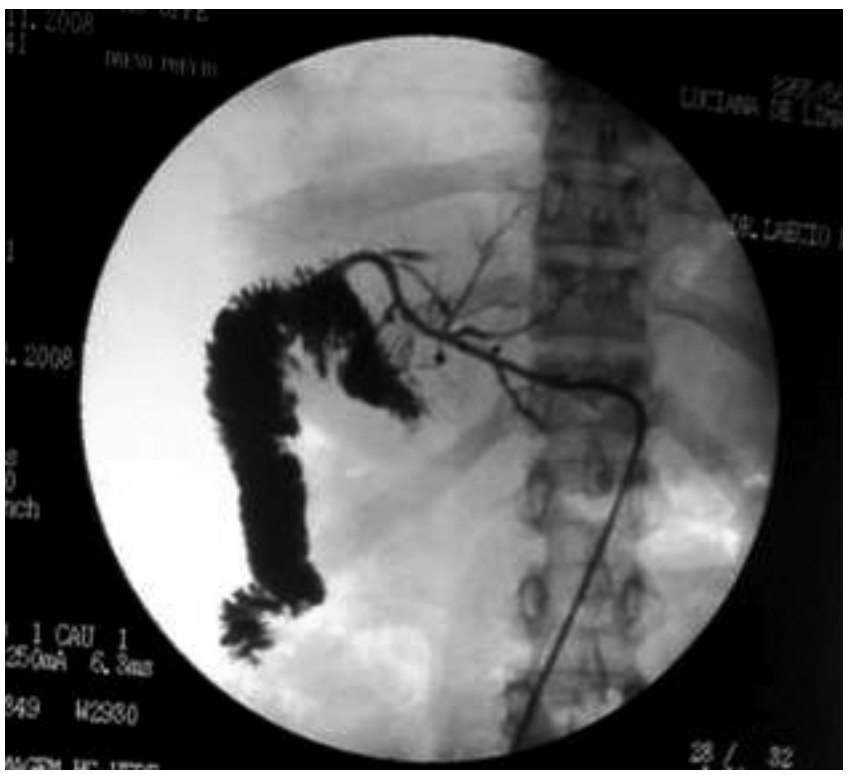

FIGURE 1 - Percutaneous cholangiogram 18 months after liver resection with short biliary stenosis 


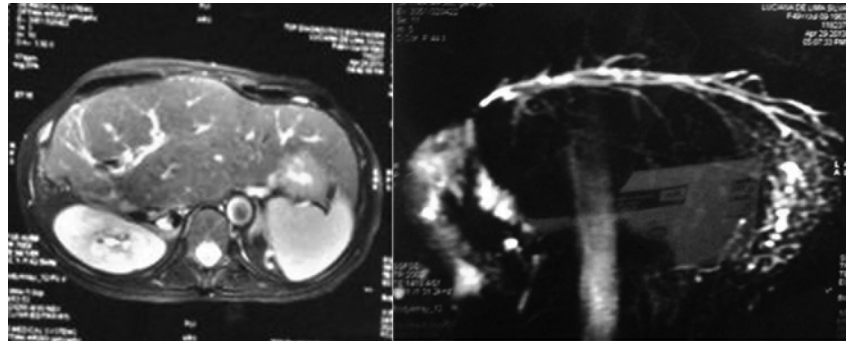

FIGURE 2 - Cholangioresonance images 18 months after liver resection: hypertrophy of the left lobe with the biliary stenosis

\section{DISCUSSION}

Simultaneous biliary and vascular damage after laparoscopic cholecystectomy worsens the clinical outlook for the patient, because of the development of biliary stenosis and hepatic necrosis ${ }^{2}$. Liver resection is usually delayed ${ }^{5}$.

The most common vascular damage associated with laparoscopic cholecystectomy is to the right hepatic artery, which is usually tolerated well ${ }^{3}$. Liver resection may be necessary in some cases in the latter stages of treatment of these patients ${ }^{4}$. It is important to note that confirmed biliary damage should be followed by investigation for concomitant arterial damage ${ }^{6}$.

Biliovascular damage also involving the portal branch is less common ${ }^{7}$. The posterior position in the portal-hepatic system provides the portal vein with some degree of protection during hepato-biliary surgery or trauma. However the occurrence of damage frequently requires liver resection as the ideal form of treatment. Different from single lesions of the right or left hepatic artery, damage to the portal branch leads to non-partial formal hepatectomies. Most reported cases state that there was no early identification of the portal damage . $^{8}$

In the case described here there was early identification of imminently life-threatening complex biliovascular damage, caused by acute liver failure ${ }^{6}$. The immediate decision to revascularize the viable liver segment and remove the ischemic, necrotic right lobe meant that there was no need for an emergency liver transplant ${ }^{9}$. It should be noted that the choice of a technical solution avoided waiting for a liver graft at a time when there is a scarcity of transplantable organs ${ }^{8}$.

\section{REFERENCES}

1. Alves $A$, Farges $\mathrm{O}$, Nicolet J, et al. Incidence and consequence of an hepatic artery injury in patients with postcholecystectomy bile duct strictures. Ann Surg 2003; 238:93-96.

2. Buell JF, Cronin DC, Funaki B, Koffron A, Yoshida A, Lo A, Leef J, Millis JM. Devastating and fatal complications associated with combined vascular and bile duct injuries during cholecystectomy. Arch Surg 2002; 137:703-708.

3. Felekouras E, Megas T, Michail OP, Papaconstantinou I, Nikiteas N, Dimitroulis D, Griniatsos J, Tsechpenakis A, Kouraklis G. Emergency liver resection for combined biliary and vascular injury following laparoscopic cholecystectomy: case report and review of the literature. South Med J. 2007 Mar;100(3):317-20.

4. Heinrich S, Seifert H, Krahenbuhl L, et al. Right hemihepatectomy for bile duct injury following laparoscopic cholecystectomy. Surg Endosc 2003; 17:1494-1495.

5. Jablónska B. Hepatectomy for bile duct injuries: When is it necessary? World J Gastroenteral 2013; 19 (38) : 6348-6352.

6. McCormack L, Quiñonez EG, Capitanich P, Chao S, Serafini V, Goldaracena N, Mastai RC. Acute liver failure due to concomitant arterial, portal and biliary injury during laparoscopic cholecystectomy: is transplantation a valid life-saving strategy? A case report. Patient Safety in Surgery 2009; 3(22):1-5.

7. Strasberg SM, Gouma Dj "Extreme vasculobiliary injuries: association witer fundus-down Cholecystectomy in severly inflamed gallbladders. HPB(ox ford) 2013; 14 (1): 1-8. 